\title{
Historia „przepisana w tym samym języku, ale od prawej strony do lewej". O Sprawie Meursaulta Camela Daouda
}

T $\$ śród narracji postzależnościowych, wykorzystujących do rozrachunków z przeszłością kanoniczne dzieła literatury europejskiej i amerykańskiej, największą bodaj sławę zdobyły te, których autorzy w roli poddawanego rewizji pre-tekstu obsadzili Robinsona Crusoe. Tę założycielską literacką apoteozę nowoczesnego kolonializmu przenicowali w swoich apokryficznych powieściach, powstałych w II połowie XX w., Michel Tournier - w szeroko dyskutowanym, zwłaszcza w latach sześćdziesiątych i siedemdziesiątych - Vendredi ou les Limbes du Pacifique oraz J. M. Coetzee w, opublikowanym w roku 1986 i po dziś dzień animującym nowe interpretacje, Foe. Wedle mojej wiedzy do czasu powstania Sprawy Meursaulta, autorstwa Algierczyka, Kamela Daouda, nikt nie próbował subwersywnie, w duchu postkolonialnym, prze-pisywać dzieł Alberta Camusa.

Sprawa Meursaulta to powieść, której apokryficzność na pozór nie mieści się, mimo nierozerwalnej więzi świata przedstawionego ze światem pre-tekstu, w żadnej z formuł, wykorzystanych przeze mnie gdzie indziej (Szajnert 2011; 2014) i zarazem paradoksalnie je wyostrza jako odpowiedź na aporie literackich narracji postkolonialnych. Narratorem i głównym bohaterem jest tu bowiem Harun Ulad el-Assas, „nędzny urzędnik inspekcji nadzoru ziemskiego" (Daoud 2015: 114), który przedstawia się jako brat bezimiennego Araba, zastrzelonego przez protagonistę Obcego, przybyłemu z Paryża młodemu badaczowi pism Camusa. Kilkadziesiąt lat po uwiecznionym w jego arcydziele wydarzeniu Harun podczas kilku wieczornych spotkań w orańskim barze ${ }^{1}$, nazywanym przez bywalców Tytanic - bo niebawem „zatonie”, jak inne miejsca, w których jeszcze podaje się alkohol — odsłania przed swoim słuchaczem ślepe plamki Camusowskiego dyskursu, snując opowieść nie tyle o tym, co „naprawdę” rozegrało się na nadmorskiej plaży w pobliżu Algieru w sierpniu 1942 roku, ile o tym między innymi, jakie były tego wydarzenia kulisy światopoglądowo-geopolityczne i —

1 A bar bywa w kulturze islamskiej traktowany jako miejsce emblematyczne: jako przestrzeń wykluczenia i zarazem oporu. 
przede wszystkim - konsekwencje egzystencjalne, moralne, ideowe dla bliskich ofiary Meursaulta. Ci bliscy to tylko matka i jej drugi, dużo młodszy syn: „żałosna para stojąca za kulisami arcydzieła, o którego istnieniu" (Daoud 2015: 115) długo nie wiedzieli. Siostry — kobiety lekkich obyczajów, której godności ofiara miałaby bronić - bracia Ulad el-Assas nie mieli.

Daoud już na wstępie informuje, co będzie tworzywem jego opowieści i zdradza cel, w jakim zostanie ono wykorzystane, oraz metodę pracy z obcą kulturą i językiem „porzuconym” przez najeźdźców na terytoriach uważanych przez nich za własne po tym, jak zostali zmuszeni do ich opuszczenia ${ }^{2}$. Z jednej strony chodzi tu o ogólną charakterystykę działań tych natywnych pisarzy, którzy posługują się językiem kolonizatora, z drugiej zaś - o wyjaśnienie własnej, autorskiej praktyki narracyjnej. Wydaje się, że wedle piszącego po francusku Daouda wszyscy ci pisarze są w pewnej mierze apokryfistami-dywersantami twórczo pasożytującymi na kolonialnym dziedzictwie literackim, a on sam - reprezentowany przez narratora Sprawy Meursaulta - kreatorem swoistej postaci apokryfu postkolonialnego, uprzywilejowującego jeden pre-tekst, i rozumianego jako produkt autoironicznej, świadomej kulturowo-literackiej kreolizacji:

Zabójca stał się sławny, a jego historia jest napisana zbyt dobrze, bym miał ją naśladować. To jego język. Dlatego uczynię to, co robiło się w tym kraju po odzyskaniu niepodległości: ze starego domu kolonizatorów kamień po kamieniu zbuduję swój dom, swój język. Słowa i wyrażenia zabójcy będą dla mnie jak porzucona własność. Kraj jest zresztą pełen słów, które już do nikogo nie należą, widnieją na szyldach starych sklepów, w pożółkłych książkach, na ludzkich twarzach; jest pełen słów zmienionych przez dziwny język, jaki tworzy dekolonizacja.

(Daoud 2015: 6) 3

Do swojej powieści Daoud przenosi między innymi „słowa i wyrażenia” z Obcego (tekst składa się nawet z takiej samej liczby słów, co ów pre-tekst), formę narracji, czyli monolog wypowiedziany — z Upadku, miejsce akcji — z Dżumy. Ofiara kolonializmu ma prawo traktować każdą z tych rzeczy jako rodzaj bona vacantia („Les mots du meurtrier et ses expreesssions sont mon bien vacant”) oraz zająć ją i adaptować do własnych celów tak, jak w wyniku dekolonizacji został zajęty czy przejęty język francuski i sfabrykowany obcy język kreolski („l'étrange

2 A. Kaplan podkreśla, że dla Daouda „język francuski nie jest już, jak za czasów Kateba Yacine’a, «łupem wojennym» [un butin de guerre], ponieważ władza w Algierii nie mówi już tym językiem” (Kaplan 2014: bns). Zob. też nieco zmieniona i poszerzona anglojęzyczna wersja tego artykułu (Kaplan 2016) oraz interesujący esej Lobny Mestaoui (2017).

3 Przekład tej metawypowiedzi na język polski sprawił, że ów — akcentowany w oryginale — współczynnik metaforycznie rozumianej kreolizacji stał się niemal niewidoczny. Por.:

Le meurtrier est devenu célèbre et son histoire est trop bien écrite pour que j'aie dans l'idée de l'imiter. C'était sa langue à lui. C'est pourquoi je vais faire ce qu'on a fait dans ce pays après son indépendance: prendre une à une les pierres des anciennes maisons des colons et en faire une maison à moi, une langue à moi. Les mots du meurtrier et ses expressions sont mon bien vacant. Le pays est d'ailleurs jonché de mots qui n'appartiennent plus à personne et qu'on aperçoit sur les devantures des vieux magasins, dans les livres jaunis, sur des visages, ou transformés par l'étrange créole que fabrique la décolonisation. (Daoud 2014: 12; podkr. D.S.) 
créole”), zmieniający dotychczasowe znaczenia. Różnica nieuchronnie stowarzyszona z tak pojmowanym przejęciem cudzej własności - tutaj cudzych słów i struktury wypowiedzenia — została zamanifestowana już w pierwszym zdaniu Sprawy Meursaulta: „Mama żyje do dziš” (Daoud 2015: 6; „Ajourd'hui, M'ma est encore vivante” — Daoud 2014: 11). Słynny incipit Obcego to wszakże „Dzisiaj umarła mama” (Camus 1972: 6; „Aujourdhu'hui, maman est morte" - Camus 1962: 9).

Język francuski, jego znajomość i nieznajomość, podziw dla mistrzostwa stylu wypowiedzi Meursaulta i dbałość o kształt wypowiedzi własnej, to przedmioty szczególnej uwagi narratora powieści. On sam opanował francuszczyznę późno - gdy miał kilkanaście lat.

Nauczyłem się tego języka [mówi] między innymi po to, żeby opowiedzieć tę historię w zastępstwie mojego brata, który przyjaźnił się ze słońcem. Wydaje ci się to niewiarygodne? Mylisz się. Musiałem znaleźć odpowiedź, której nikt nie chciał mi udzielić, kiedy należało to zrobić. Najpierw język się chłonie, potem się nim mówi, aż któregoś dnia to on zaczyna tobą władać; wtedy zazwyczaj zamiast ciebie chwyta sens rzeczy, zagarnia usta jak kochanek w żarliwym pocałunku.

(Daoud 2015: 11)

By zostać usłyszany (stać się widzialny) musiał „opowiedzieć tę historię” po francusku. W Obcym Arabowie są wszakże niemi: „za cały język starcza im dźwięk fletu” ‘ (Daoud 2015: 7). Inną motywacją do nauki była wiara, że francuski, fascynujący Haruna „jako pewna zagadka, której rozwiązanie rozstrzygnęłoby dysonanse” w jego „świecie” (84), „mógłby położyć tamę między” nim a „szaleństwem matki”. „Żeby przetrwać” musiał poznać „inny język niż jej” — taki, „który nie jest jej mową. Jej bogatą, obrazową, żywą mową, z niedostatku precyzji pełną uniesienia i improwizacji” (38). Harun podziwiał tę mowę, ale nie chciał, by nim zawładnęła. Naprawdę „wstrząsający język, którym można inaczej opowiedzieć świat” (91); język, „który lśni jak diament" (91), odkrył dopiero po przeczytaniu Obcego. O istnieniu tego dzieła usłyszał jako człowiek już dorosły.

Swojej nadal żyjącej matce, a zatem i matce zabitego przez Meursaulta „Araba”, Harun przypisuje bardzo ważną rolę w opowiadanej przez siebie historii. Impulsem dla podjęcia własnej opowieści nie była nagła śmierć starszego brata, zastępującego mu w dzieciństwie nieobecnego, "porwanego przez wiatr” (Daoud 2015: 38) ojca (tak m.in. narrator pseudonimuje fakt, iż ów ojciec opuścił rodzinę) tylko to, jak została przedstawiona w tej sławnej książce.

Edward Said, pisząc o twórczości Camusa, zwraca uwagę, że

[c]zytelnicy zwykle łączą jego powieści z francuskimi powieściami o Francji, nie tylko z powodu języka i formy [...], ale również dlatego, że wybór Algierii jako miejsca akcji wydaje się przypadkowy w obliczu naglących zagadnień moralnych. Niemal pół wieku od powstania czytywane są one zatem jako przypowieści o kondycji ludzkiej. To prawda, Meursault zabija Araba, ale ten

4 Por. oryginal (Camus 1962: 89) i przekład (Camus 1972: 44). 
Arab nie zostaje nazwany i wydaje się nie mieć historii, nie wspominając już o matce i ojcu. To również prawda, że Arabowie umierają w Oranie na dżumę, ale oni też nie zostają nazwani, natomiast na pierwszy plan wysuwają się Rieux i Tarrou. Mówi się zwykle, że należy czytać te teksty dla zawartego w nich bogactwa, a nie dla tego, co zostało (jeśli coś rzeczywiście zostało) usunięte. Ja jednak twierdzę, że w powieściach Camusa można znaleźć coś, z czego, jak sądzono, zostały już oczyszczone - a mianowicie szczegóły na temat francuskiego podboju imperialistycznego, który rozpoczął się w 1830 roku, trwał za życia Camusa i wpłynął na kompozycję jego dzieł.

(Said 2009: 189; podkr. D.S.)

Ten dotyczący m.in. Obcego projekt „kontrapunktowej” lektury, przedstawiony przez autora Orientalizmu, mógłby być źródłem inspiracji dla Daouda. To właśnie bezimienność zabitego, absolutny brak zainteresowania ofiarą nie tylko ze strony zabójcy czy tych, którzy go sądzili, ale też uczonych egzegetów jego słynnego monologu, a nawet ze strony czytelników arabskich, zmusiły protagonistę Sprawy Meursaulta do przeprowadzenia własnego dochodzenia - czy raczej kontrdochodzenia (contre-enquête) — w sprawie brata, Musy.

Dobry Boże, jak można zabić kogoś i odebrać mu nawet jego śmierć? To mój brat zginął od kuli, a nie on! Musa, a nie Meursault, no nie? Jest coś, co mnie zdumiewa. Nikt, nawet po odzyskaniu niepodległości, nie był ciekawy, jak brzmiało nazwisko ofiary, gdzie mieszkała, kim byli jej przodkowie, ewentualne dzieci. Nikt. Wszyscy oniemieli z zachwytu nad doskonałością języka, który lśni jak diament, i współczuli pogrążonemu w samotności zbrodniarzowi, składając mu niesłychanie uczone kondolencje.

(Daoud 2015: 8-9; podkr. D.S.)

W „przeklętej książce” francuskiego autora „było [...] wszystko z wyjątkiem najważniejszego: imienia Musy! Nie było go nigdzie. Liczyłem raz i drugi, słowo «Arab» pojawiało się dwadzieścia pięć razy, a nie było imienia nikogo z nas" (Daoud 2015: 108; podkr. D.S.). Takie skargi Harun ponawia wielokrotnie; boleje, że mimo iż jego brat miał imię i nazwisko,

na zawsze pozostanie Arabem. [...] Kolonizator od wieków rozszerza swój stan posiadania, nadając nazwy temu, co sobie przywłaszcza, i odbierając je temu, co staje mu na przeszkodzie. Jeśli nazywa mojego brata Arabem, to aby go zabić, jak zabija się czas, przechadzając się bez celu.

(Daoud 2015: 16) 
Arab wszakże

to byt ulotny, przeżył dwie godziny i jest martwy od siedemdziesięciu lat, bez przerwy, nawet po swoim pogrzebie.

(Daoud 2015: 8)

Francuski autor nie zdobywa się nawet na ponowienie gestu Robinsona Crusoe. Mógłby przecież nadać tubylcowi imię „Czternastek” — od godziny, w której został pozbawiony życia ${ }^{5}$. „Po arabsku Zudż, czyli dwa [...]" (Daoud 2015: 8); tak będzie czasem nazywany przez Haruna.

Według niego bycie Arabem jest ,jak murzyńskość, która istnieje tylko poprzez spojrzenie białego” - nie ono stanowiło o społecznej i jednostkowej tożsamości. „W naszej dzielnicy, która była dla nas całym światem, było się muzułmaninem, miało się imię, twarz i zwyczaje. Kropka. Oni byli «obcymi» [...]” (Daoud 2015: 58). Obcy — rumi czy gauri — pozostają takimi w spojrzeniu tutejszych. Czy „tutejsi” uważali się za Algierczyków? — o tym Daoud nie pisze, ale żali się, że „nikt nie zadał sobie pytania, jakiej narodowości był Musa. Nawet wśród Arabów był nazywany Arabem. Powiedz, czy „Arab” to jest narodowość? Gdzie jest ten kraj, który wszyscy uznają za swe łono, swoje trzewia, ale którego nigdzie nie ma (Daoud 2015: 123). Camus natomiast podawał w wątpliwość istnienie „narodu algierskiego” roszczącego pretensje do uzyskania niepodległości narodowej. Uważał, że temu „potencjalnemu narodowi” mogliby przewodzić „Żydzi, Turcy, Grecy, Włosi czy Berberowie”, ponieważ „całej Algierii nie tworzą sami Arabowie”. Współtworzą ją zwłaszcza francuscy kolonowie. „Francuzi w Algierii są również jej rodowitymi mieszkańcami” pisał (Camus 1965: 2012-13), pośrednio wyjaśniając po latach, dlaczego nie wyróżniał tych spośród jej mieszkańców, który nazywał Arabami ${ }^{6}$. Daoud oczywiście zna zarówno poglądy Camusa — zaskakująco zgodne z francuską, oficjalną wizją politycznej geografii Algierii jako pozostającej w nierozerwalnej

5 Tak - na wzór „Piętaszka”, wymyślonego w translacji W.L. Anczyca - imię „Quatorze heures“ przełożyła tłumaczka Sprawy Meursaulta. Por.: „Il aurait pu l'appeler «Quatorze heures» comme l’autre a appelé son nègre «Vendredi»" (Daoud 2014: 13).

6 Co ciekawe, w Crise en Algérie Camus upierał się właśnie przy istnieniu narodu arabskiego i oponował przeciw charakterystycznej dla Francuzów skłonności do lekceważącego postrzegania go jako anonimowej, zdezindywidualizowanej masy:

Sur le plan politique, je voudrais rappeler aussi que le peuple arabe existe. Je veux dire par là qu'il n'est pas cette foule anonyme et misérable, où l'Occidental ne voit rien à respecter ni à défendre... Ce peuple n'est pas inférieur, sinon par la condition de vie où il se trouve, et nous avons des leçons à prendre chez lui, dans la mesure où il peut en prendre chez nous. Trop de Français, en Algérie ailleurs, l'imaginent par exemple comme une masse amorphe que rien n'intéresse. (Camus 1965: 942)

Gdzie indziej pisał o dziecinnym marzeniu o zniknięciu Francji i niemożności wyeliminowania z Agierii „sprawy francuskiej”, podkreślając, że Francuzi i Arabowie są skazani na wspólne życie na jej ziemiach:

nous sommes condamnés à vivre ensemble... Le ‘fait français' ne peut être éliminé en Algérie et le rêve d'une disparition subite de la France est puéril. Mais, inversement, il n'y a pas de raisons non plus pour que neuf millions d'Arabes vivent sur leur terre comme des hommes oubliés... (Camus 1958: 126).

Na temat kwestii algierskiej: antykolonialnej aktywności Camusa w latach trzydziestych (chodzi tu przede wszystkim o cykl reportaży Misère de la Kabylie, opublikowanych w 1939 r. przez algierskie czasopismo „Alger républicain") oraz jego kategorycznego sprzeciwu wobec terroryzmu po obu stronach walczących w wojnie algierskiej zob. m.in.: Carrol 2008; Ansel 2012; Kaplan 2012. Ansel podkreślał jednak, że nawet mimo masakry w Kabylii w 1945 r., Camus nie przestawał wierzyć w cywilizacyjną misję Francji. W Chronique Algérienne stale „apelował o politykę zadośćuczynienia, politykę dialogu, porozumienia, koncyliacji” (Ansel 2012: 49), ufając 
unii z Francją — jak i argumenty tych camusologów, którzy próbowali usprawiedliwić jego stanowisko w sprawie suwerenności tego kraju, ale ślady owej wiedzy są w monologu Haruna zatarte, niemal niewidoczne. Najważniejszym układem odniesienia pozostaje dla niego $O b c y$.

Chociaż w apokryficznej powieści Daouda odwołaniami do tego tekstu inkrustowana jest cała przemowa narratora, zanim opowie on swojemu słuchaczowi (którego bezmownych reakcji, rzadkich pytań i innych replik domyślamy się tylko dzięki sygnałom, odpowiedziom i powtórzeniom wpisanym do wypowiedzi bohatera) o tym, jak dowiedział się o istnieniu książki z opowieścią Meursaulta i co wyniknęło z konfrontacji z historią przez niego przedstawioną, usłyszymy, kim byli ci, dla których nie było w niej miejsca i jak wyglądało życie rodziny po śmierci Musy. Zapoznamy się razem z owym słuchaczem z „idiotycznym”, w opinii Haruna, prywatnym śledztwem w tej sprawie, w którym był zmuszony uczestniczyć już jako dziecko, a prowadzonym przez jego niepiśmienną matkę przez lata kultywującą surową żałobę, w której ważną rolę odgrywały odwiedziny pustego grobu na algierskim cmentarzu Al Kattar i gloryfikujące syna-męczennika zmyślone opowieści. Po bezowocnych staraniach o uzyskanie bliższych informacji o tym, co stało się z Musą (w jakich okolicznościach i dlaczego zginąt?) i z ciałem Musy, którego „nigdy nie odnaleziono” (Daoud 2015: 34), matka i syn opuszczają znienawidzony Algier; przenoszą się do Hadżut, miejscowości oddalonej od przeklętego morza, które zabrało Musę. „Odsunęliśmy się z matką możliwie najdalej od szumu fal” (Daoud 2015: 29) — tak skwitował tę decyzję Harun.

Hadżut to arabska nazwa Marengo; tam mieścił się przytułek, w którym zmarła matka Meursaulta. Tam też rozegrała się scena wielokrotnie wcześniej zapowiadana przez narratora, decydująca o przynajmniej deklaratywnym zakończeniu żałoby i późniejszym rozpoznaniu wspólnoty z bohaterem Obcego: scena zabójstwa Francuza - acte gratuit albo akt zemsty. Ofiara Haruna miała imię i nazwisko. To Joseph Larquais, krewny właścicieli farmy, u których służyła matka w zamian za mieszkanie w nędznym baraku. Po ich ucieczce dawni służący zajęli, w akcie dziejowej sprawiedliwości, opuszczony dom.

Nie chcę zgrywać ofiary, ale te parę metrów, które dzieliło naszą klitkę od domu kolonizatora, kosztowało nas lata ciężkiego, mozolnego marszu przez błota i ruchome piaski, jak w koszmarnym śnie. Trzeba było ponad dziesięciu lat, żebyśmy wreszcie położyli na nim rękę i uznali go za wyzwolony: to nasze! Tak, tak, zrobiliśmy to, co wszyscy w pierwszych dniach niepodległości, roztrzaskaliśmy drzwi, zabraliśmy talerze i świeczniki.

(Daoud 2015: 31)

W ten sposób mówi o tym Harun. Odpowiedzialność za strzały oddane przez siebie o drugiej w nocy, 5 lipca 1962 roku, a więc dwadzieścia lat po śmierci Musy, do przerażonego, szukającego schronienia w tymże domu rumiego zrzuca na księżyc — „To tam, w Hadżut, pewnej strasznej nocy, księżyc kazał mi dopełnić dzieła, które twój bohater rozpoczął w słońcu” (Daoud 2015: 33), wyznaje swojemu słuchaczowi - i na matkę. To ona przez cały czas pielęgnowała myśl o zemście, powiada. „To ona prowadziła moją rękę, podczas gdy Musa

w możliwość sprawiedliwej reformy systemu kolonialnego, ale takiej, która nie naruszałaby kluczowej zasady podległości, na której był ufundowany. 
prowadził jej rękę i tak dalej, aż do Abla lub jego brata” (84). To ona wreszcie utrzymywała, że antypatyczny Joseph musiał zostać ukarany, bo „uwielbiał kąpać się w morzu o czternastej, [...], za bardzo lubił morze [...] i za każdym razem wracał stamtąd zbyt żywy" (102-103), co miało też stanowić dowód jej szaleństwa: opętania śmiercią starszego syna na nadmorskiej plaży o tejże godzinie i zniewolenia syna młodszego przytłaczającą pamięcią o tym wydarzeniu, a nawet poczuciem winy, że żyje. „Mama przekazała mi swoje lęki, a Musa swojego trupa. Jak sądzisz, co ma zrobić młody człowiek uwięziony między matką a śmiercią?” (41-42) pyta po latach swego słuchacza. Matkę według Haruna „zniknięcie Musy [...] rozbiło, ale, paradoksalnie, wtajemniczyło również w perwersyjną przyjemność przeżywania niekończącej się żałoby” (37) zmienionej „w zadziwiającą komedię, którą odgrywała wspaniale, czyniąc z niej niemal arcydzieło" (34).

Swoją winę Harun przedstawia rozmaicie; oskarża się albo usprawiedliwia. Tym, co pośród innych przyczyn prezentuje jako absurdalno-groteskowe źródło własnych udręk związanych ze zbrodnią, jest fakt, iż „nowi władcy” (Daoud 2015: 90) Algierii nie oskarżyli go o jej popełnienie - o zabicie przypadkowej osoby - tylko o to, że zrobił to w nieodpowiednim momencie. Co prawda, „wszędzie w kraju umierali jacyś Francuzi, podobnie zresztą jak Arabowie” (Daoud 2015: 89), „zabijało się wtedy dużo, niemal na oślep: zabijali ludzie z OAS, ale także dżundiowie, którzy załapali się do FLN na ostatni moment (Daoud 2015: 74), ale zdaniem przesłuchującego Haruna pułkownika armii wyzwoleńczej, zadziwionego i rozbawionego tym, że przyszło mu sądzić Algierczyka za zabójstwo Francuza, „[t]rzeba było zabić tego Francuza razem z nami, w czasie wojny, a nie w tym tygodniu. [...] Trzeba to było zrobić przed. [...]. Przed piątym lipca! Tak, przed, a nie po, do jasnej cholery”. Wątpliwości zabójcy (po pierwsze - „wiele by to nie zmieniło”, po wtóre: nie wiadomo, czy „piątego lipca o drugiej w nocy [...] była jeszcze wojna, czy już niepodległość”) (Daoud 2015: 100) budzą wściekłość oficera. Harun wie ponadto, że w oczach Algierczyków jego największym przewinieniem pozostają inność czy obcość, automatycznie rozpoznawane u tych, którzy nie walczyli jak ich rówieśnicy, nie wstąpili do partyzantki. Wojnę wyzwoleńczą „wygraliśmy [...] już wcześniej, z chwilą, kiedy moi bliscy byli mordowani z powodu czyjegoś znużenia i udaru" (Daoud 2015: 14-15) — w ten oto sposób tłumaczył po latach swój brak zaangażowania. Ale za ów dystans do emocji podzielanych przez większość rodaków też nie został wtedy ukarany.

Mieli mnie uwolnić bez żadnego wyjaśnienia, a ja chciałem zostać skazany. Chciałem pozbyć się tego cienia, który mi ciążył i zamienił moje życie w mrok. Było wręcz coś niesprawiedliwego w tym, jak mnie puścili, nie wyjaśniając mi nawet, czy jestem przestępcą, zabójcą, zmarłym, ofiarą czy może po prostu niezdyscyplinowanym idiotą. Lekceważenie, z jakim potraktowano moją zbrodnię, uznałem niemal za obrazę. Zabiłem i wprawiło mnie to w niesamowite upojenie. Nikt jednak nie dostrzegł w tym nic niewłaściwego. Zdaje się, że jakimś problemem był jedynie rozkład dnia. Co za niedbalstwo i dezynwoltura! Nie zdawali sobie sprawy, że w ten sposób przekreślają mój czyn, unicestwiają go? Daremność śmierci Musy była nie do przyjęcia. A teraz moja zemsta miała być równie nieważna!

(Daoud 2015: 101-102) 
Podobnie jak w przypadku Jean-Babtiste’a Clamence’a nie do końca wiadomo, czy Harun odgrywa przed swoim słuchaczem komedię udręczonego sumienia, czy mówi serio; czy rzeczywiście - o czym świadczą niektóre jego wypowiedzi ${ }^{7}$ — odebranie komuś życia traktuje jako kardynalne doświadczenie graniczne, czy raczej jako wydarzenie niewiele znaczące, naturalną konsekwencję zamiany ról ofiary i kata, zgodnej z ludowymi wyobrażeniami o sprawiedliwości ${ }^{8}$. A może po prostu zmienia kwalifikację swego czynu w zależności od efektu, jaki chce wywołać na aktualnym etapie wywodu. Gorzko-ironiczne motto powieści („Godzina zbrodni nie dla wszystkich ludów bije w tym samym czasie. Tak tłumaczy się trwałość historii") zaczerpnięte z Sylogizmów goryczy Emila Ciorana ${ }^{9}$, licuje z każdą z tych interpretacji sugerowanych w monologu narratora. Odniesienie do dwu zabójstw, kluczowych w jego opowieści — co podkreśla, gdy mówi do swego słuchacza: „[t] wój bohater dobrze to wiedział, zabójstwo jest jedyną kwestią, którą powinien się zajmować filozof. Cała reszta to czcze gadanie" (Daoud 2015: 84) ${ }^{10}$ - nie wyczerpuje oczywiście sensu tego epigrafu, korespondującego z tym, co Daoud ma do powiedzenia o dawnej i obecnej sytuacji swojego kraju. Jednak i tu widoczna jest tendencja szczególnie wyraźnie objawiająca się wtedy, gdy w zmetaforyzowanej, wolnej od jednoznaczności wypowiedzi Haruna pojawiają się nazwy odsyłające do pojęć stereotypowo kojarzonych z myślą Camusa - takich na przykład jak 'obcość' czy 'absurd'. Harun zazwyczaj ostentacyjnie je ukonkretnia czy ulokalnia, niejako wbrew ich uniwersalistycznym pretensjom filozoficznym, po to, by uczynić bliższymi doświadczeniu własnemu i doświadczeniu jemu podobnych. Nie rezygnuje przy tym z przedstawień figuralnych. „Jeśli chodzi o absurd” - powiada — „to nikt inny, tylko mój brat i ja niesiemy go na naszych barkach, drzemie on w łonie naszej ziemi” (Daoud 2015: 11; podkr. D.S.). Chodziło tu przede wszystkim o „absurd jego śmierci” (24), który „uderzył w [...] świat” Haruna i matki (37). Absurdalność sytuacji tego bohatera „polegała na tym, że musiał[em] pchać trupa na szczyt góry, zanim znów stoczy się w dół, i tak bez końca” (48). Josepha zabił, „bo trzeba było przeciwwagi” (110) dla tej sytuacji. Gdy mówi, że „[ś]mierć w pierwszych dniach

\section{Np.:}

W bezkarnym zabójcy rodzi się skłonność do lenistwa. Ale i coś nie do naprawienia: zbrodnia na zawsze niszczy miłość i możliwość kochania. Zabiłem i od tamtego czasu życie przestało być dla mnie święte. [...] Zabijając jednego człowieka, unicestwiłem wszystkie ludzkie ciała. Zresztą, drogi przyjacielu, jedyny werset Koranu, który dźwięczy mi w głowie, brzmi: "Ten, kto zabił człowieka, [...] czyni tak, jakby zabił wszystkich ludzi". (Daoud 2015: 86)

8 Np.: „Ja też zabiłem, zgodnie z życzeniem tej ziemi, pewnego dnia, kiedy nie miałem nic do roboty” (Daoud 2015: 52).

9 W przekładzie Ireneusza Kani.

Może się wydawać, że tendencyjnie zniekształca tu słynne dictum Camusa z dzieła, w którym dał on — według Sartre’a - „wyjaśnienie swej powieści” (Sartre 1973: 234), czyli z Mitu Syzyfa: „Jest tylko jeden problem filozoficzny prawdziwie poważny: s a m o b ó j s t w o" (Camus 1971: 91; podkr. D.S.). Daoud jednak odsyła tu zapewne do znaczącej korektury, zapowiedzianej przez Camusa we Wprowadzeniu do opublikowanego dwadzieścia lat później Cztowieka zbuntowanego: „W czasach negacji zastanawianie się nad problemem samobójstwa mogło być pożyteczne. W czasach ideologii należy dojść do ładu z zabójstwem” (Camus 1991: 8). Można się spierać, czy Meursault był świadomym „człowiekiem absurdu”, ale do zbrodni przez niego popełnionej doskonale pasuje charakterystyka zarysowana w tymże $W$ prowadzeniu -

Poczucie absurdu, jeśli chce się w nim znaleźć reguły postępowania, czyni zabójstwo co najmniej obojętnym, a w rezultacie możliwym. Jeśli w nic się nie wierzy, jeśli nic nie ma sensu i jeśli nie możemy uznać żadnej wartości, wszystko jest możliwe i żadna rzecz nie ma znaczenia. Nic za, nic przeciw, zabójca ani ma rację, ani jej nie ma. [...] W jakąkolwiek [...] stronę się obrócić, zabójstwo zajmuje uprzywilejowane miejsce w sercu negacji i nihilizmu. (Camus 1991: 9) 
niepodległości była tak samo bezcelowa, absurdalna i nieoczekiwana jak śmierć na zalanej słońcem plaży w 1942 roku" (Daoud 2015: 97), zdaje się zakładać, że istnieją nie tylko śmierci oczekiwane, ale też celowe i nieabsurdalne.

Usytuowane w ten sposób wykorzystanie słowa absurd i pochodnych — na określenie tego, z czym nie sposób się pogodzić, jak nagła śmierć brata, narzucone przez matkę nieustanne rozpamiętywanie straty i koncentracja na „ostrzeniu noża rodzinnej zemsty” (Daoud 2015: 38), ale też kolonialna podległość — koresponduje w monologu Haruna z naiwnym, wydawałoby się, utożsamianiem autora i narratora „przeklętej książki”, którą przeczytał po raz pierwszy dopiero dwadzieścia lat po jej wydaniu, zatem z utożsamianiem autora i zabójcy Musy. Książka:

[b]yła niewielka. Na okładce zreprodukowano akwarelę przedstawiającą mężczyznę w garniturze, z rękami w kieszeniach, zwróconego tyłem do morza. Pastelowe, blade kolory. Tytuł brzmiał $O b c y$, nazwisko zabójcy było napisane prostymi czarnymi literami po prawej stronie u góry: Meursault.

(Daoud 2015: 114) ${ }^{11}$

Ta książka jest co rusz przywoływana przez Haruna jako dzieło Meursaulta właśnie. Podczas któregoś ze spotkań w orańskim barze bohater powieści Daouda utrzymuje nawet, że ów autor-narrator-zabójca nie został stracony, bo „[p]o wyjściu [...] z więzienia pisze książkę, która staje się głośna, i opowiada w niej, jak stawiał czoło swemu Bogu, księdzu i absurdowi" (Daoud 2015: 52). Chwilę później jednakże Harun desperacko szuka czegoś, co wyjaśniłoby „powód zwolnienia zbrodniarza skazanego na śmierć, w dodatku już po egzekucji, fakt, że nigdy nie odnaleziono mojego brata, oraz to, dlaczego podczas procesu sądzono człowieka, który niedostatecznie opłakał śmierć swojej matki, a nie człowieka, który zabił Araba" (Daoud 2015: 54; podkr. D.S.). Brak wystarczających podstaw, by rozstrzygnąć, czy jest tu mowa o niezasłużonej - metaforycznie rozumianej - nieśmiertelności Meursaulta, uczynionego autorem równie „nieśmiertelnej” opowieści, czy raczej powinniśmy potraktować ten passus jako kolejne świadectwo niepewnego albo intencjonalnie niestabilnego statusu zdarzeń i postaci przywołanych w „kabotyńskim” (Daoud 2015: 47) monologu Haruna. Kolejne, ponieważ zdarza mu się pośrednio podawać w wątpliwość nie tylko rzeczywiste istnienie bohaterów dzieła Camusa ${ }^{12}$, ale też istnienie Musy czy obsadzenie go w roli ofiary uwiecznionego w Obcym zabójstwa (zob. Daoud 2015: 43) i swoje z nią pokrewieństwo. Być może jednak i tu źródłem owych niejasności jest to, co — jak twierdzi Harun — w czasach kolonializmu nie było niczym nadzwyczajnym: algierscy nędzarze nie mieli dokumentów potwierdzających

11 Ten opis okładki odsyła do kieszonkowej publikacji Obcego przez wydawnictwo Gallimard w 1957 roku. „[P]rostymi czarnymi literami” po lewej, a nie „prawej stronie u góry” było tam oczywiście zapisane nazwisko Albert Camus.

12 Np. z faktu, że na cmentarzu w Hadżut nie znalazł grobu matki zabójcy Musy i nikt ze starych mieszkańców tej miejscowości nie przypominał sobie żadnego chrześcijańskiego pogrzebu sprzed lat wyprowadza wniosek, że Meursault kłamie, a „jego matka, to nie ta, o której myślimy” (Daoud 2015: 33), o Rajmundzie mówi: „zastanawiam się, czy w ogóle kiedykolwiek istniał; ten, który miał być powodem śmierci mego brata i tego całego zamieszania z moralnością, dziwkami i honorem” (42). Gdzie indziej wspomina o miejscu „bez adresu, gdzie zabójca nigdy nie przyszedł na świat" (Daoud 2015: 53; podkr. D.S.). 
ich tożsamość, aktów urodzenia czy zgonu. To jedna z przyczyn, dla których matka nie mogła dowieść, że ma prawo do renty po Musie: przekonać nowych władz do uznania go za zamordowanego przez Francuza szahida ${ }^{13}$.

Z jednej zatem strony Daoud mnoży chwyty uwierzytelniające historię przedstawioną przez Haruna, z drugiej - dyskretnie sugeruje, że narrator Sprawy Meursaulta prowadzi ze swoim słuchaczem grę, co prawda nie tak wyrafinowaną retorycznie jak ta, której promotorem jest Jean-Babtiste Clamence, ale nie mniej dwuznaczną. Ergo: utożsamiający rolę autorską i narratorską Harun nie jest aż tak naiwny, jak mogłoby się wydawać, a twórca tej postaci, świadomy potencjału afektywnego nie-fikcji, próbuje subtelnie - tak by nie nadwątlić dywersyjnego wydźwięku własnego przekazu - przysłonić aż nadto oczywiste tropy prowadzące do identyfikacji arcydzielnego, niewątpliwie fikcjonalnego, pre-tekstu, wielokrotnie nb. poddawanego stronniczo redukcyjnym streszczeniom.

Sprawa jeszcze bardziej się komplikuje, gdy uwzględnimy różnice, pominięte z konieczności w tłumaczeniu na język polski, dzielące arabskie i francuskie wydania Meursault, contre-enquête ${ }^{14}$. W wersji opublikowanej w 2013 r. w Algierze, zabójcą i autorem podziwianej i zarazem potępianej przez Haruna książki pod tytułem "Obcy” (L'Etranger) jest Albert Meursault. W edycji powieści Daouda udostępnionej rok później we Francji autor nie tylko nie ma już wspólnego z Camusem imienia — nazywa się „Meursault”, a był to nb. jeden z używanych przez twórcę Obcego pseudonimów - ale też zmieniony został tytuł przypisanego mu tekstu; jego dzieło to „Inny” (L'Autre) ${ }^{15}$. Zdaniem Alice Kaplan przy pomocy formuly "Albert Meursault" Daoud podkpiwa ze swych rodaków skłonnych do obarczania Camusa winami jego bohaterów i narratorów. Badaczka nie znajduje jednak żadnego przekonującego uzasadnienia dla przemianowania pre-tekstu Sprawy Meursaulta ${ }^{16}$. A przecież zastąpienie "obcego" uświęconym przez współczesną filozofię (w tym także przez urodzonego w Algierii Jacquesa Derridę) „innym”, czy raczej „Innym”, powinno skłaniać do zastanowienia. Jeśli Daoud chciał zwrócić uwagę na przeistoczenie się obcego w Innego - w alter ego - w nowym świetle stawiał podobieństwo łączące Haruna z Meursaultem. To światło pozbawia waloru bezwzględności zarówno absolutyzowaną Inność, jak i obcość.

Odebranie opowieści Meursaulta statusu literackiej fikcji jest też jednym z chwytów uwierzytelniających emocjonalne zaangażowanie protagonisty utworu Daouda w ocenę ukazanych w niej wypadków. Harun nota bene nie posługuje się nazwą powieść: nigdy nie nazywa pre-tekstu swego monologu inaczej niż „książką” (livre) czy historią (bistoire). Mamy wierzyć, że dotyczy i dotyka go ona osobiście, bo rolę pozbawionej znaczenia ofiary odgrywa w niej

13 Jak opisuje to Harun:

[P]rzez lata po odzyskaniu niepodległości Mama walczyła o rentę dla matki męczennika. Słusznie się domyślasz, że nigdy jej nie dostała; zgadnij dlaczego. Nie można udowodnić, że Arab był synem — i bratem. Nie można udowodnić, że w ogóle istniat, choć przecież został publicznie zamordowany. Nie można znaleźć i potwierdzić związku między Musą a Musą! Jak to powiedzieć ludzkości, kiedy nie umie się pisać książek? (Daoud 2015: 16-17)

W edycji polskiej zamieszczono informację o tych dwu wydaniach jako podstawie przekładu. Jego autorka wybrała z pierwszego tytuł książki, o której mowa, z drugiego natomiast — pozbawioną imienia nazwę autora.

Por. fragment cytowany przeze mnie na podstawie przekładu na język polski i dwie wersje francuskojęzyczne: „Le titre en était L'Etranger, le nom de l'assassin était écrit en lettres noires et strictes, en haut à droite: Albert Meursault” (Daoud 2013: 171); „Le titre en était L'Autre, Le nom de l'assassin était écrit en lettres noires et strictes, en haut à droite: Meursault" (Daoud 2014: 137).

16 Nie są nim z pewnością obowiązujące we Francji przepisy prawa autorskiego, na które się powołuje. Zob. Kaplan 2016: 343 . 
jego własny brat. Również Marjam, dzięki której Harun dowiaduje się o istnieniu i sławie tejże książki, uważa ją za dzieło niefikcyjne czy przynajmniej inspirowane zdarzeniami autentycznymi. Ta młoda Algierka, pracująca nad rozprawą doktorską poświęconą jego autorowi, zadała sobie przecież trud odnalezienia krewnych Araba zabitego przez bohatera, którego ów autor upamiętnił. Wedle Haruna miała nawet powiedzieć, że książka, o której mowa, „została napisana przez [...] zabójcę" (Daoud 2015: 112).

Marjam dotarła do Hadżut u progu lata 1963 roku i wprowadziła w życie protagonisty — wierzącego, że zabicie Francuza ostatecznie zakończyło rodzinną żałobę po Musie - zamęt. Jego źródłem była nie tylko owa „przeklęta” książka i to, że oburzeniu bohatera na jej twórcę towarzyszył podziw dla mistrzostwa tejże. Dwudziestosiedmioletni Harun bowiem zakochał się - po raz pierwszy i ostatni w życiu. Całkowicie różna od dziewcząt z sąsiedztwa Marjam, która „uważała się za «kobietę wolną»” (Daoud 2015: 115), wyzwoloną dzięki przeczytanym przez nią książkom, jak mówiła, spod władzy konserwatywnej rodziny, wzbudziła w nim uczucia wcześniej nieznane. Dzięki niej miał „poznać to, co Mama zawsze czujnie neutralizowała: żar, pożądanie, fantazje, oczekiwanie, szał zmysłów” (Daoud 2015: 116). Jednakże po kilku tygodniach zakazanej przez matkę znajomości Marjam zniknęła na zawsze. „Od początku wiedziałem, że nasza historia się zakończy, ponieważ jestem przeklęty” (119) — oto, wedle Haruna, jedno z wyjaśnień jej kresu. „Uwięziony między matką a śmiercią” młody człowiek nie mógł zatrzymać pięknej, wykształconej, przenikliwie inteligentnej, zdobywczej, nieuległej kobiety, należącej, jak mówił, „do gatunku [...], który dziś już zanikł w tym kraju” (121).

Naruszając spokój — burząc mały, względnie uładzony, zamknięty świat Haruna — Marjam otworzyła go na świat dotąd niedostępny. To z nią wyszlifował swój francuski, co było warunkiem dogłębnego poznania takich książek, po jakie wcześniej nigdy nie sięgał: przede wszystkim arcydzieła francuskiego autora - o którym mówił potem, że zna je na pamięć i może „wyrecytować w całości jak Koran” (Daoud 2015: 8) — oraz pozostałych tekstów, których ów autor był twórcą. Ona odsłoniła sens tegoż arcydzieła i zapisane w nim „niezwykłe obrazy samotności” (118); wprawiła w zachwyt nad jego oszałamiającym językiem. Nauczyła je czytać tak, by mimo gniewu na autora Harun mógł go jednocześnie podziwiać i - choć w tym już zapewne nie miała udziału — rozpoznać łączące go z nim zdumiewające pokrewieństwo. Oto jego słowa:

Szukałem tam śladów mojego brata, a znalazłem swoje odbicie, odkrywając, że jestem niemal sobowtórem zabójcy. Doszedłem do ostatniego zdania książki: „[...] pozostało mi jeszcze pragnąć, by w dniu mojej egzekucji było dużo widzów i by mnie powitali okrzykami nienawiści”. Boże, jak ja bym tego chciał! [...].

Te ostatnie linijki mną wstrząsnęły. To arcydzieło [...]. Lustro, w którym widzę swoją duszę i to, czym miałem się stać w tym kraju, między Allahem a znudzeniem.

(Daoud 2015: 117)

O odkryciu, że książka ta nie tylko „wspaniale kłamie”, ale też w „magiczny sposób zgadza się z [...] życiem” (Daoud 2015: 49) bohatera i narratora Sprawy Meursaulta, byliśmy informowani już wcześniej. Daoud raz po raz odsłania jakieś analogie - niezbyt doniosłe w gruncie 
rzeczy, ale przyciągające uwagę czytelników - między światami całkowicie wydawałoby się odmiennych protagonistów dwu różnych powieści: obaj, na przykład, wychowują się bez ojców; nie mają nic do powiedzenia swoim starym, bardzo rzadko odwiedzanym matkom, których wieku nie znają ani nie spodziewają się usłyszeć od nich niczego nowego; kobiety, z którymi się spotykają, mają pokrewne - wywodzące się z tego samego źródła - imiona. Pierwsze znaczące podobieństwo między Meursaultem a Harunem objawia się w momencie popełnionej przezeń zbrodni, uwięzienia oraz absurdalnego przesłuchania, podczas którego okazuje się, że jego wina polega nie na tym, że się tej zbrodni dopuścił, tylko na tym, iż nie dokonał jej „we właściwym momencie” (Daoud 2015: 98); rumi wszakże był sądzony nie za to, że zabił Araba, lecz za to, że nie płakał na pogrzebie matki. To podobieństwo umacnia się później w związku z miejscem, w którym tkwi główny bohater powieści Daouda, czyli — jak sam to ujął - „między Allachem a znudzeniem”. Ale to miejsce nie przestaje zarazem dzielić bohaterów, bo Daoud nie rezygnuje z kwestionowania uniwersalistycznych roszczeń Camusowego filozofowania. Nie pozwalają o tym zapomnieć sceny z nieodległej przeszłości miejsca.

Historia Haruna „przypomina opowieść o początku: Kain przybył tu, by zbudować swoje miasto i ulice, ujarzmić ludzi, ziemię i korzenie" (Daoud 2015: 56). Niemniej

[p]rawda jest taka, że niepodległość tylko skłoniła jednych i drugich do zamiany ról. My byliśmy duchami tego kraju, gdy kolonizatorzy go wykorzystywali i obnosili się ze swoimi dzwonami, cyprysami i bocianami. Dziś? Jest na odwrót! Wracają tu czasem, trzymając za ręce potomków, przyjeżdżają z wycieczkami dla pieds-noirs, lub dla dzieci nostalgicznych rodziców, szukają jakiejś ulicy, domu czy pnia drzewa z wyciętymi inicjałami. Niedawno widziałem grupę Francuzów na lotnisku przed sklepem z tytoniem. Niczym dyskretne i nieme zjawy patrzyli na nas, Arabów, w milczeniu, zupełnie jakbyśmy byli kamieniami lub uschniętymi drzewa mi. Przecież teraz to już skończona sprawa. To mówiło ich milczenie.

(Daoud 2015: 14; podkr. D.S.)

Francuzi zatem patrzą teraz na Arabów tak, jak w czasach podległości Arabowie patrzyli na nich ${ }^{17}$. Być może jednak rzeczywiście jedni i drudzy patrzyli i milczeli „po swojemu”.

Oni byli „obcymi”, rumimi, sprowadzonymi przez Boga, żeby wystawić nas na próbę, ale ich godziny tak czy inaczej były policzone; któregoś dnia musieli odejść, to pewne. Dlatego nie odpowiadaliśmy im, milczeliśmy w ich obecności i czekaliśmy, oparci o mur. [...] Każdy z nas o tym wiedział, i to od wczesnego dzieciństwa, nie musieliśmy nawet o tym mówić, wiedzieliśmy, że w końcu odejdą. Kiedy zdarzało nam się przechodzić przez europejskie dziel-

17 Por. „Zobaczyłem grupę Arabów, stali wsparci plecami o witrynę sklepu z tytoniem. Patrzyli na nas w milczeniu, po swojemu, zupełnie jakbyśmy byli kamieniami lub uschniętymi drzewami” (Camus 1972: 38). 
nice, mieliśmy nawet taką zabawę, wskazywaliśmy palcem poszczególne domy i dzieliliśmy je między siebie jak wojenny łup: „Ten jest mój, byłem pierwszy!”, rzucał jeden z nas, krzycząc jak podczas licytacji. W wieku pięciu lat! Zdajesz sobie sprawę? Jakbyśmy przeczuwali, co — poza walką zbrojną — zdarzy się po wyzwoleniu.

(Daoud 2015: 58-59; podkr. D.S.)

Zamiana ról, której pokrewieństwo wiążące Haruna z Meursaultem wydaje się paradoksalną poniekąd konsekwencją, polegała więc — o czym była już tutaj mowa - m.in. na anektowaniu miejsc wcześniej zajmowanych przez „obcych”. W pierwszych dniach niepodległości „Francuzi miotali się w potrzasku między morzem a klęską, gdy tymczasem [...] rodacy cieszyli się, podnosili, ubrani w swoje kombinezony, budzili się ze sjesty pod skałami i teraz to oni zaczynali zabijać” 18 (Daoud 2015: 72). Potem walkę o władzę wszczęli zwycięscy dowódcy. Jeszcze później Harun obserwuje ,jak wypala się euforia niepodległości, jak rozwiewają się złudzenia” (123). Z czasem narasta w nim poczucie obcości wobec tych, w których imieniu występuje, domagając się przepisania opowieści Meursaulta „w tym samym języku, ale od prawej strony do lewej” (Daoud 2015: 8; podkr. D.S.). Staje się coraz bardziej krytyczny. Arabowie, powiada, przestali już sprawiać „wrażenie”, jakby „na coś czekali”, teraz kręcą się „w kółko bez celu” (Daoud 2015: 123).

Mówiąc o sobie, że mieszka „w tym kraju jak inni, ale z większą rezerwą i obojętnością” (Daoud 2015: 123), zżymając się na ograniczenia w produkcji i sprzedaży alkoholu, wszakże „W raju leje się on strumieniami” (51), czy na sąsiada, „który ubzdurał sobie, by w każdy weekend przez całą noc głośno recytować Koran” (64), obwieszczając swą nienawiść do piątków, a zwłaszcza „do godziny modlitwy [...]. Głosu imama, który wrzeszczy przez głośnik, zwiniętego pod pachą dywanika modlitewnego, jazgotu minaretów, jarmarcznej architektury meczetu i tej obłudy, z jaką wierni spieszą ku wodzie i złej wierze, ablucjom i recytacji” oraz deklarując wrogość do „religii. Wszystkich! Bo zafałszowują wagę świata (66-67), i odnotowując, przy innej okazji, że wtedy, gdy „zabijał, Bóg nie był jeszcze aż tak ważny w tym kraju i nie ciążył nam tak jak dziś (Daoud 2015: 82), Harun wskazuje na to, co stanowi największe zagrożenie dla indywidualnej wolności, której sens i doniosłość odkrył dzięki lekturze „przeklętej książki” przypisanej, być może przewrotnie, Meursaultowi. O tym, jak ważna jest dla niego wolność, przekonuje droga, jaką przebył od sarkastycznego porównania religii do transportu publicznego i wyboru samotnej, pieszej wędrówki do Boga „jeśli trzeba, ale nie w ramach zorganizowanej wycieczki” (Daoud 2015: 64) do ekstatycznego wyznania niewiary w finale powieści - literalnie, z niewielkimi tylko zmianami, przepisanego z monologu oczekującego na egzekucję Mersaulta. Przynajmniej niektóre z tych zmian nie są jednak bez znaczenia. Harun nie relacjonuje rozmowy z księdzem, tylko z imamem, do którego mówi „proszę pana” zamiast „szajchu”, a nie „mój ojcze”; chwyta imama „za kołnierz gandury”, a nie księdza za kołnierz sutanny ${ }^{19}$ — słowem: scena, o której opowiada, nie rozgrywa się we francuskiej kolonii, lecz w niepodległej Algierii, gdzie islam jest zapisaną w konstytucji religią państwową. „Mieszkasz gdzie indziej, nie możesz pojąć, co musi znosić starzec, który nie

18 W taki zatłuszczony kombinezon ubrana była ofiara Meursaulta (Camus 1972: 44). 
wierzy w Boga, nie chodzi do meczetu, nie oczekuje raju, nie ma żony ani syna i prowokacyjnie obnosi się ze swą wolnością" (Daoud 2015: 126) — żali się swemu słuchaczowi. Wolnością, powtórzę, wyczytaną — jak powiada — z książek i języka bohatera jego studiów. To one sprawiły, że Harun zaczął „inaczej nazywać rzeczy i porządkować świat za pomocą własnych słów” (Daoud 2015: 38). Inaczej niż jego otoczenie i inaczej niż autor tych książek. Daoud mówi o innych opresjach niż Camus w Obcym - bliższych tym, które przedmiotem pogłębionej refleksji stały się dopiero w Cztowieku zbuntowanym, z którego autor Sprawy Meursaulta zapożyczył też m.in. figurę i rolę Kaina, w różnych konfiguracjach pojawiającego się w monologu Haruna.

Zdaniem Lobny Mestaoui język byłego kolonizatora okazał się dla Daouda i jego bohatera,

paradoksalnie, pięćdziesiąt lat po uzyskaniu niepodległości i zadrażnieniach [crispations] tożsamościowych, czy to o charakterze religijnym, czy nacjonalistycznym, symbolem wyzwolenia od „Tekstu ujarzmiającego” [„Texte ligoteur”], jak mówi Djaout ${ }^{20}$, wskazując na Koran i wraz z nim wszelką mowę uświęcającą, która hamuje myśli.

(Mestaoui 2017: 145)

Daoud wykorzystuje zatem francuski - nie tylko francuski Camusa - jako język wolności, twórczości i zarazem subwersji. Od czasu, gdy Harun opanował podstawy tego języka, matka zmuszała go do tłumaczenia dwu, przechowywanych przez nią jak relikwie, gazetowych wycinków, w których mowa była o zabójstwie Musy wedle jednej wersji pojawiającego „się tam w postaci dwóch marnych inicjałów” (Daoud 2015: 107), wedle innej - nienazwanego nawet w tak zredukowany sposób (zob. Daoud 2015: 96). By sprostać oczekiwaniom matki, chłopiec przez dziesięć lat, ciągle na nowo, apokryficznie przetwarzał te skąpe, składające się z kilku linijek wzmianki: zastępował je rozbudowaną opowieścią z mnóstwem wymyślonych przez siebie szczegółów, przekształcał „w tragedię”, opisując całą „scenę i słynną plażę [...] ziarnko po ziarnku” (Daoud 2015: 108), rozdmuchiwał „do rozmiarów jakiegoś kosmosu”, bo mama — jak twierdził — „miała prawo do szczegółowej rekonstrukcji zbrodni” (109).

Porzucił jednak pomysł, żeby zapisać to, co wtedy powstało, bo nie wiedział, jak tego dokonać; nie podejrzewał też, że „zbrodnia może zamienić się w książkę, a ofiara stać się zwykłym błyskiem ostrego światła” (Daoud 2015: 10). Przeczytawszy tę książkę zrozumiał, że bez jej uwzględnienia niepodobna opowiedzieć własnej historii. Tę misję powierzył swojemu słuchaczowi:

Odpowiada ci moja historia? To wszystko, co mogę ci dać. Moje słowa weź albo wyrzuć. Jestem bratem Musy albo niczyim bratem. Zwykłym mitomanem, którego spotkałeś, by zapisać zeszyt... To już twój wybór, przyjacielu. To jak z biografią Boga. Ha, ha! Nikt go nigdy nie spotka1, nawet Musa, nikt nie wie, czy jego historia jest prawdziwa, czy też nie. Arab to Arab, Bóg to Bóg. Żadnych

20 Tahar Djaout był algierskim dziennikarzem i pisarzem pochodzącym z Kabylii. Jako gorący orędownik świeckości państwa w 1993 r. został zamordowany przez islamistów. 
nazwisk, żadnych inicjałów. Kombinezon i niebieskie niebo. Dwaj nieznajomi i dwie historie na plaży bez końca. Która jest bardziej prawdziwa? Intymne pytanie. Ty zdecydujesz. El Mersul! Ha, ha.

(Daoud 2015: 129)

Powinniśmy zatem uwierzyć, iż lekturę owej drugiej historii, prze-pisanej z pierwszej w języku francuskim, „ale od prawej strony do lewej”, zawdzięczamy właśnie temu, przybyłemu z Paryża „stenografowi”, spragnionemu jakichś nowych informacji o pisarzu, którym się zajmuje. Być może rzeczywisty autor powieści siebie obsadził w roli owego słuchacza i zarazem jej „autora” fikcjonalnego. Na okładce jego książki nie figuruje wszakże nazwisko Haruna Ulada el-Assasa, tak jak na rzeczywistej okładce Obcego nie figuruje nazwisko Meursaulta.

Sprawa Meursaulta - dzieło „człowieka zbuntowanego” - nie jest jednakże tylko wyrazem pryncypialnego sprzeciwu wobec narzuconej, europejskiej spuścizny, wcześniej (bywało) bezrefleksyjnie albo koniunkturalnie przyjmowanej w ramach praktyk asymilacyjnych i akulturacyjnych. Nie sposób też uważać powieści Daouda jedynie za manifest niezgody na równie pryncypialne, postkolonialne odrzucenie całości tej spuścizny w imię mitów nacjonalistycznych czy religijnych. Powieść ta przede wszystkim utwierdza w przekonaniu o ważności krytycznego, subwersywnego przepracowania obcego dziedzictwa i doświadczenia na własnej skórze, jak trudne i zarazem wyzwalające może być otwarcie na dywersyjny potencjał ukryty w arcydzielnych tekstach pochodzących spoza własnego kręgu kulturowego.

Katedra Teorii Literatury Instytutu Kultury Współczesnej, Wydział Filologiczny Uniwersytetu Łódzkiego

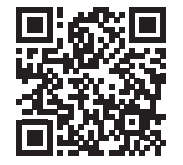




\section{Bibliografia}

Ansel Yves (2012), Albert Camus, totem et tabou, politique de la postérité, Presses universitaires de Rennes, Renne.

Camus Albert (1958), Actuelles III. Chronique Algérienne, Éditions Gallimard, Paris.

- (1962), L'étranger, Éditions Gallimard, Paris.

- (1965), Essais, Éditions Gallimard, Paris.

- (1971), Eseje, przeł. J. Guze, PIW, Warszawa.

- (1972), Obcy, przeł. M. Zenowicz [w:] tegoż, Obcy. Dżuma. Upadek, Wydawnictwo Literackie, Kraków.

- (1991), Cztowiek zbuntowany, przeł. J. Guze, Oficyna Literacka Res Publica, Kraków.

Carroll David (2008), Albert Camus the Algerian: Colonialism, Terrorism, Justice, Columbia UP, New York.

Daoud Kamel (2013), Meursault, contre-enquête, Editions barzakh, Alger.

- (2014), Meursault, contre-enquête, roman, Éditions Actes Sud, Arles.

- (2015), Sprawa Meursaulta, przeł. M. Szczurek, Wydawnictwo Karakter, Kraków.

Kaplan Alice (2012), New Perspectives on Camus's Algerian Chronicles [w:] Camus A., Algerian Chronicles, ed. Kaplan A., trans. A. Goldhammer, Harvard UP, Cambridge, MA.

- (2014), „Meursault, contre-enquête” de Kamel Daoud, „Contreligne” juin, https://www.academia.edu/35346618/_Meursault_contre-enqu\%C3\%AAte_de_Kamel_Daoud [dostęp: 17.05.1019].

— (2016), Making „L'Etranger” contemporary: Kamel Daoud's „Mersault contre-enquête” [w:] Being Contemporary. French Literature, Culture and Politics Today, eds. Brozgal L., Kippur S., Liverpool UP, Liverpool.

Mestaoui Lobna (2017), Le «butin de guerre» camusien, de Kateb Yacine à Kamel Daoud, „Babel. Littératures plurielles” (36), http://journals.openedition.org/babel/5002 [dostęp 12.01.2020].

Said Edward (2009), Kultura i imperializm, przeł. M. Wyrwas-Wiśniewska, Wydawnictwo UJ, Kraków.

Sartre Jean-Paul (1973), Komentarz do „Obcego” Camusa, przeł. J. Prokop [w:] Sztuka interpretacji, t. II, wybór i oprac. H. Markiewicz, Zakład Narodowy im. Ossolińskich, Wrocław - Warszawa - Kraków - Gdańsk.

Szajnert Danuta (2011), Dywersyjny potencjat apokryfu, „Zagadnienia Rodzajów Literackich”, z. 2. - (2014) The Subversive Potential of an Apocryphon [w:] Critical Theory and Critical Genres. Contemporary Perspectives from Poland, eds. Russell Ch., Melberg A., Płuciennik J., Wróblewski M., Peter Lang, Frankfurt am Main - Bern - Bruxelles.

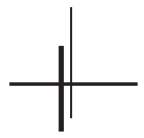

